\title{
Properties and Performance of Ultrafine Grained Titanium for Biomedical Applications
}

\author{
Daniel Jogaib Fernandes ${ }^{a *}$, Carlos Nelson Elias ${ }^{a}$, Ruslan Zufarovich Valiev ${ }^{b}$ \\ ${ }^{a}$ Laboratory of Biomaterials, Instituto Militar de Engenharia - IME, \\ CEP 22290-270, Rio de Janeiro, RJ, Brazil \\ ${ }^{b}$ Institute of Physics of Advanced Materials, Ufa State Aviation Technical University, \\ Ufa 450000, Ufa, Russia
}

Received: May 7, 2015; Revised: August 29, 2015

\begin{abstract}
The use of materials for biomedical applications has become vital to enhance the quality of life and longevity of human beings. Commercially pure titanium (cpTi) and titanium alloys are the most adequate materials for some biomedical applications, but cpTi and the Ti-6Al-4V alloy (Ti G5) have limitations for biomedical application due to low mechanical strength and the possibility of ion release, respectively. In order to address this problem, commercially pure ultrafine grained titanium (UFG Ti) obtained by severe plastic deformation (SPD) has been suggested as a promising alternative for biomedical applications. This thermomechanical process is able to improve the strength of cpTi and titanium alloys while keeping their excellent biocompatibility. The purpose of this review was to compare the mechanical strength of UFG Ti, cpTi and a Ti G5 alloy. In addition, the biological performance of UFG Ti was also evaluated by in vivo testing. Prodigious improvements were seen in surface topography, wettability and in homogeneity of oxide layer. The overall improvements in microstructure provided by ECAP technique coupled with surface etching resulted in a remarkable performance of cpTi alloy for biomedical applications.
\end{abstract}

Keywords: titanium, mechanical properties, biocompatibility, biomedical, biomaterials

\section{Introduction}

The area of human implants has undergone rapid and dramatic developments in the recent past. This was greatly enabled by new materials with enhanced biocompatibility. Although implants have been used by humans since ancient times, there were many rejection problems and it is only recently that materials for osseointegrated implants have been developed. Materials for this purpose are not necessarily organic but must exhibit specific properties ${ }^{1}$. Biocompatibility is, obviously, the most desirable property ${ }^{2,3}$. In addition, corrosion resistance to body fluids as well as mechanical strength, fatigue endurance, and toughness are also desirable features of a biomaterial, especially for implant applications ${ }^{4-6}$. Biomaterials are usually classified, in terms of their interaction with the body ${ }^{7}$, as biotolerant, bioinert and bioactive.

- Biotolerant materials (e.g., stainless steel, CrCo alloy, and polymethyl-methacrylate) release substances in nontoxic concentrations, which may lead to the formation of a fibrous connective tissue. Valiev ${ }^{8}$ reported on several applications for non-osseointegrated medical devices made with biotolerant materials. Plate implants for bone fixation and screws are the most common.

- Bioinert materials (e.g., alumina and zirconia) exhibit minimal chemical interaction with adjacent tissue. A fibrous capsule may be formed around such materials.

*e-mail: djfernandes@ime.eb.br
- Bioactive materials (e.g., hydroxyapatite, bioglass) stimulate a biological response from the body, such as bonding to a tissue, which may be soft (cartilage) or hard (bone).

According to Hench \& Jones $^{9}$, there are two classes of bioactive materials: osteoconductive and osteoproductive. Osteoconductive materials (e.g., synthetic hydroxyapatite and tricalcium phosphate) are able to bond to hard tissue. Osteoproductive materials (e.g., unalloyed titanium, tantalum and niobium) stimulate the growth of new bone onto the surface of the biomaterial and spontaneously bind to living bone cells, if they have been previously subjected to a surface treatment. The osteoconductiveability can be more deeply explored if the activation and recruitment of osteoprogenitor cells are taken into account ${ }^{10}$.

Gene activating materials (e.g., titanium nanotubes) stimulate cells to express gene factors necessarys for a specific role. The biocompatibility of the material and its osteoinductive behavior should be addressed as results of gene expression. The main idea of this generation of materials is to stimulate the expression of factors instead of just introducing them ${ }^{11}$.

The effects of the titanium nanotubes have been described according to the expression profiling of osteoblasts cultivated on cpTiand nanotubes titanium disks. The quantitative expression of the mRNA for transcriptional factors and for bone related genes are up-regulated in primary osteoblasts cell cultures cultivated on titanium nanotubes surface ${ }^{11}$. 
Another way to change cell expression is related to chemical modification of the titanium surface to produce a micro and nanoroughness with increased wettability and surface energy ${ }^{12}$. Even though changes in the surface roughness of osteoproductive materials have already been shown to increase the overall level of cytokine gene expression necessary for macrophage activation, it was recently reported that chemical modification of the titanium surface leads to additional improvements in osseointegration due to increased hydrophilicity ${ }^{12,13}$. Hamlet et al. ${ }^{13}$ showed that surface hydrophilicity decreased the gene expression of cytokine, down-regulating factors $(\mathrm{Ccl}-2$ and $\mathrm{TNF} \alpha)$ related to giant cells and to the generation of MMP9 cells. In this way, hydrophilicity inhibits apoptosis of biomaterial adherent macrophages and stimulates macrophage fusion. From a clinical perspective, this process activates M2 cytokine and thus attenuates pro-inflammatory response, facilitating healing and osseointegration ${ }^{13,14}$.

Therefore, metals such as cp Ti, Ta and $\mathrm{Nb}$ can be called bioactive ${ }^{15}$. Figure 1 shows SEM details of bone adhered to the implant surface. In fact, cpTi is reported to be an effective bioactive material ${ }^{16}$. The main application of bioactive unalloyed cpTi (ASTM grade 1 to 4 ) is for dental implants. This metal is not, however, used for orthopaedic application owing to its low mechanical strength.

This review work focuses on dental implants and in the introduction of ultrafine grained titanium (UFG Ti), obtained by severe plastic deformation (SPD) processing, for which recent properties were evaluated ${ }^{17}$. In particular, its strength was found to match that of Ti-6Al-4V alloy, commonly used in high strength structural implants.

\section{Dental Implants}

\subsection{Brief history}

When Brånemark ${ }^{18}$, in the early 1960s, was studying blood flow in bone marrow, he never thought about the revolution that he was about to trigger. He used metallic hollow implants (chambers) that traversed the tibia of rabbits and enabled observation, through a glass window, of the marrow. Upon removing these implants at the end of the experiment in order to reuse them, he observed that some of the implants were firmly attached to the bone and some even sheared off. The reader can imagine what an average researcher would have possibly done. Most probably, use a few strong words and have the machine shop make new ones. That was not Brånemark reaction. He realized that some of the stainless steel implants had been replaced by titanium, and these were the ones that were firmly bonded to the bone. He immediately abandoned his research and, in a stroke of genius, dedicated the next fifty years to the study of osseointegration. The emergence of titanium dental implants is the result of this discovery. In the United States of America, close to one million dental implant are implanted each year, and a majority of dentists is qualified for the new field of implantology. In Brazil, the market of dental implants is close to 2.0 million a year. Worldwide, over 250 million persons lack teeth. Beyond official statistics this number could be one billion. Moreover, it is predicted that by 2030 more than 272,000 hip replacements will be performed only in United States ${ }^{19}$. Hence, the potential of this technique is virtually limitless.

\subsection{Characteristics of medical alloys}

Metallic alloys employed for biomedical purposes include stainless steel, cobalt-chromium, niobium, tantalum, titanium and exhibit several characteristics than when synergically combined allow the metallic structure to stay for a long lifetime in the human body.

Titanium is known in the medical field for its excellent combination of mechanical strength (Table 1), corrosion resistance and biocompatibility ${ }^{19}$. Pure titanium is the material of choice due to it good compatibility with human tissue, although its low mechanical strength, especially under cyclic loads, insufficient hardness and low wear resistance can lead to implant failure ${ }^{20,21}$. The durability of medical implants is an important concern in order to avoid repeated surgical operations to replace implants compromised by fatigue ${ }^{22}$.

The excellent corrosion resistance, chemical inertness and biocompatibility of titanium are ascribed to a $\mathrm{TiO}_{2}$ oxide layer. This oxide layer acts as a force field natively formed when the material is exposed to oxygen and its thickness is between 4 and $12 \mathrm{~nm}$, depending on the characteristics of the Ti alloy. In Figure 1, the oxide layer of UFG cpTi can be seen as a continuous film with a thickness of about $8 \mathrm{~nm}$ (Figure 2). Alloying elements, in the form of oxides, can

Table 1. Mechanical properties of cpTi, UFG Ti and Ti-6Al-4V alloy for implants applications and bone.

\begin{tabular}{|c|c|c|c|c|}
\hline $\begin{array}{l}\text { Types o Titanium } \\
\text { for Implants }\end{array}$ & $\begin{array}{c}\text { Yield Strength } \\
\text { (MPa) }\end{array}$ & $\begin{array}{l}\text { Ultimate Tensile } \\
\text { Strength (MPa) }\end{array}$ & $\begin{array}{c}\text { Elongation } \\
(\%)\end{array}$ & Reference \\
\hline cpTi grade 1 & 170 & 240 & 24 & \multirow{5}{*}{ ASTM F $67^{23}$} \\
\hline cpTi grade 2 & 275 & 345 & 20 & \\
\hline cpTi grade 3 & 380 & 450 & 18 & \\
\hline cpTi grade 4 & 483 & 550 & 15 & \\
\hline Ti-6Al-4V grade 5 & 795 & 860 & 10 & \\
\hline $\begin{array}{l}\text { UFG Ti grade } 2 \\
4 \mathrm{XH}+\mathrm{CR}(70)^{(1)}\end{array}$ & 796 & 877 & 18 & $\begin{array}{c}\text { Estrin et al. }{ }^{20}, \\
\text { Handtrack et al. }^{21}\end{array}$ \\
\hline UFG Ti grade 4 TMT + A $(6 \mathrm{~h})^{(2)}$ & 1110 & 1250 & 13 & Truong et al. ${ }^{19}$ \\
\hline UFG Ti grade 4 TMT $+\mathrm{A}(1 \mathrm{~h})+\mathrm{W}^{(3)}$ & 1200 & 1430 & 12 & Truong et al. ${ }^{19}$ \\
\hline Bone & $90-120$ & $90-130$ & $1-4$ & Saitova et al. ${ }^{22}$ \\
\hline
\end{tabular}




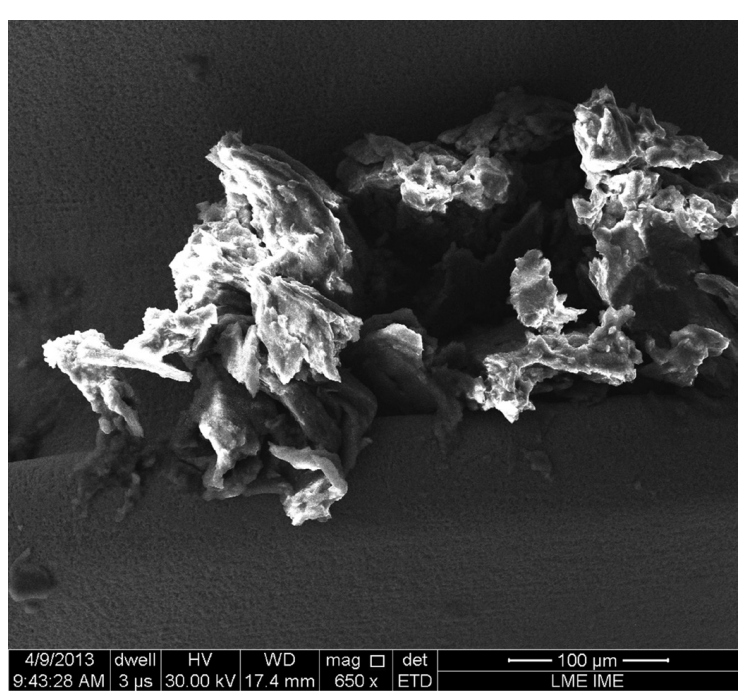

Figure 1. SEM details of the immature bone tissue adhered to the implant surface.

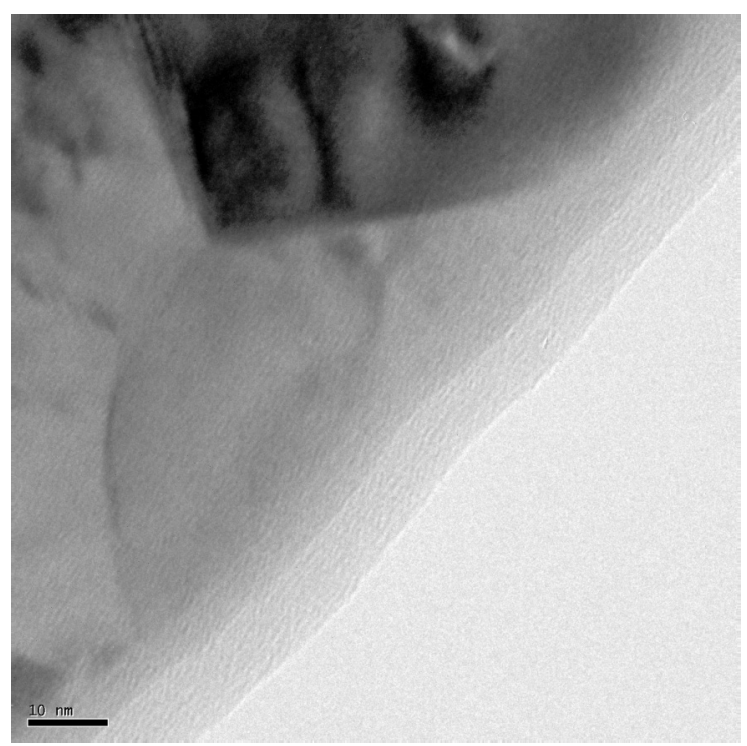

Figure 2. Native UFG cpTi oxide layer as a continuous film with thickness of about $8 \eta \mathrm{m}$. be incorporated into the layer, influencing the ability of the film to absorb proteins ${ }^{24}$.

Rutile and anatase, the most common polymorph variants of titanium oxide, have a tetragonal structure, almost the same band-gap energy (3.0 and $3.2 \mathrm{eV}$, respectively) and display about the same biocompatibility due to the formation of $\mathrm{OH}^{-}$groups on the surface. Rutile is more stable even at high temperatures and has a more compact crystal structure ${ }^{11,25,26}$. Rutile is more adequate for applications as a blood compatible material while anatase is used for biomimetical deposits of bonelike apatite ${ }^{25}$.

Generally, an ideal alloy for biomedical applications should have high mechanical strength, low density, elastic modulus lower than that of cortical bone and as similar as possible to cancellous bone, fatigue endurance, impact toughness, low toxicity, strong affinity to human bone, and easy forming/processing ${ }^{27}$.

\subsection{Osseointegration}

Osseointegration is defined as the ability of a material to combine with bone tissue, enabling the replacement of load-bearing organs in order to restore form and function. The intimate contact between bone and implant occurs at the cellular level and results in the firm adhesion of the bioactive material, to the host bone ${ }^{28}$.

The cellular interactions at the surface of cpTi occur through weak forces such as van der Waals interactions and hydrogen bridges. The binding energies of these two mechanisms, $10 \mathrm{Kcal} / \mathrm{mol}$ and $1.1 \mathrm{Kcal} / \mathrm{mol}$, respectively, are different because the first arises from molecular electric dipole interactions, while the second results from attractive interactions between hydrogen and highly electronegatively atoms such as nitrogen, oxygen and fluoride. Ionic and covalent bonds (10-100 kcal/mol) are established with defects on the surface of the material such as cations, anions and impurity atoms ${ }^{28}$. Cellular interactions of biomedical devices begin with blood linkage (Figure 3a), homeostasis, and fibrin blood clot. The first cells to appear on the surface during blood contact (adsorption), coagulation and fibrinolytic steps are ordinary blood cells such as platelets, monocytes, polymorphonuclear granulocytes and erythrocytes ${ }^{29}$. The interaction among bone-like cells begins with reorganization of their cytoskeleton, concomitant with information interchange between cells

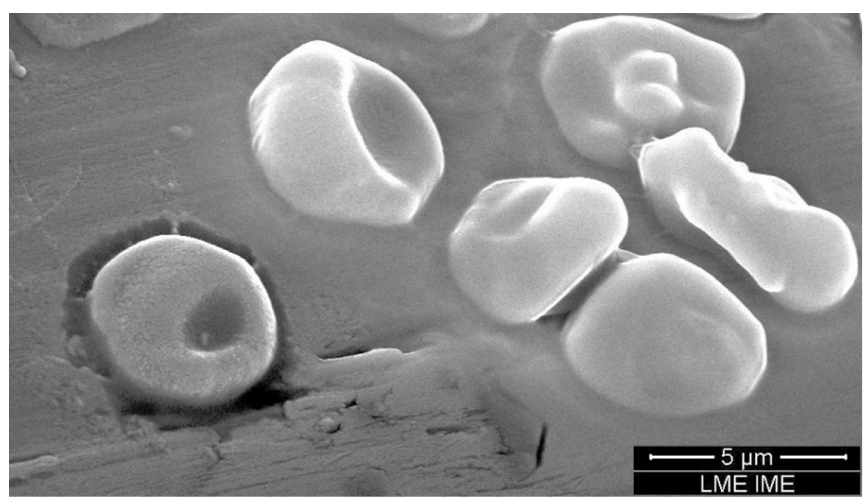

(a)

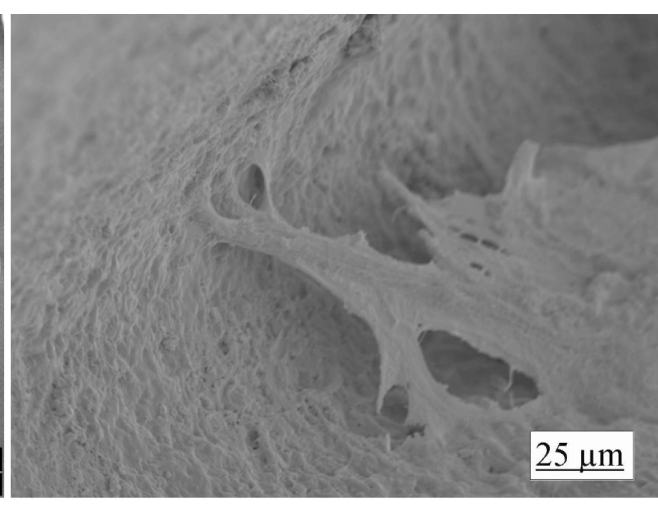

(b)

Figure 3. Cellular interaction after 8 weeks: (a) blood cells and (b) osteoblast attachments on surface of titanium mini implants. 
and the extracellular matrix, allowing gene activation and specific tissue remodeling. Adhesion of osteoblasts on the surface of the biomaterial surface is not enough to assure integration with the host bone; intracellular signals are necessary to modulate cell proliferation ${ }^{30}$. Different proteins can be deposited on the material surface, as morphogenic protein-2 or fibronectin who induce osteoblastic cell division after adhesion ${ }^{30}$. Fibronectin acts due to its amino acid sequence, which is able to signaling for activation of cells cycles, resulting in improvements of cells division ${ }^{29}$.

The surface morphology of the implant affects attachment, proliferation, extracellular matrix synthesis, growth factor release and cytokine production. The first events associated with the surface involve adsorption of molecules from the neighboring fluid, from which a signaling interface allows different cell interactions. Topography and surface chemistry control cell adsorption, attachment and alignment. The attachment mechanism determines the cell shape and this change is transmitted by the cytoskeleton to the nucleus from where different mediators are expressed.

The surface of the biomaterial is also able to enhance the adsorption of specific proteins that trigger the mechanisms of osseointegration when a bioactive material like cpTi is used as an implant.

Surface properties, such as morphology, roughness, oxide layer thickness, impurity level and oxide type influence implant osseointegration. The cpTi is currently widely used for implants owing to its recognized capacity of osseointegration. It has a surface that is covered with an oxide layer. The exact nature of osseointegration is not well understood, but cells have to adhere to the titanium oxide surface of the implant. Just a few moments after contact with the physiological environment, a large array of biomolecules, different factors as I, III, IgG and numerous blood plasma components and leukocytes can be adsorbed to the implant surface ${ }^{28}$.

After surface treatment, the $\mathrm{Ti}$ oxide layer is mainly composed by anatase and rutile These crystal structure of these titanium oxides together with surface characteristics, chemical composition and topography can influence the absorption of molecules from body fluids like blood and saliva. By controlling these parameters, one can optimize bone anchoring of biomedical implants during the early stages of osseointegration ${ }^{31-33}$.

Surface wettability is a measure of the surface energy, which is highly related to the great extension of grain boundaries of UFG titanium ${ }^{34}$. Surfaces with large energy exhibit high wettability because the solid-liquid interface decreases the energy. In order to explain the good blood compatibility of Ti oxide films, Shao et al. ${ }^{35}$ considered the influence of the blood-biomaterial interfacial tension on activation of fibrinogen by an electrochemical reaction between the protein and the titanium surface. One of the most important parameters for blood compatibility is the absorption of plasma proteins and this property is usually driven by electrostatic interactions between proteins and the surface by means of its hydrophillicity ${ }^{25}$. Another mechanism for protein absorption by titanium oxide is its ability to absorb calcium ions, as shown by a high adherence of plasma proteins like prealbumin, albumin and immunoglobins ${ }^{25}$. If a $\mathrm{TiO}_{2}$ layer is present, mainly in nanocrystalline form, water dissociation leads to increased electronegativity which improves the capture and neutralization of different types of cations. Therefore, negatively charged biomolecules such as proteins can arrive and attach to bone, producing precursors of tissue formation ${ }^{36}$.

Considering the Ti polymorphism, much attention is being given to anatase due to its photocatylic activities ${ }^{32,37}$. UV radiation is able to produce hydrophilic surfaces containing photogenerated $\mathrm{Ti}^{3+}$ defect sites. The hydrophilic surface contributes to dissociative water absorption while apatite formation results from the abundant titanium hydroxide groups ${ }^{37}$. In this way, the layer is able to absorb water, forming basic Ti-OH groups which are responsible to induce apatite nucleation and crystallization.

In vivo and in vitro experiments show that osteoblasts may completely and efficiently cover the cpTi surface, as illustrated in Figure 3b. Actually, the osseointegration mechanisms involve two main types of cells, osteoblasts and osteoclasts. The first are related to the creation of new bone and the second to removal of necrotic bone produced by drilling. The spreading out and osteoblast attempt for attachment in titanium surface can be seen in Figure $3 \mathrm{~b}$.

These cells are elongated along the machining groove orientation. It is clear that the roughness, chemical composition, energy, and wettability of the surface play an important role in osseointegration. The acid etching and anodizing of the surfaces have been shown to improve the strength of the bonds $^{29}$. This strength, developed at the interface between the implant and the bone during placement (Figure $4 \mathrm{a}$ ), can be measured by the removal torque, using an inverse procedure. The removal torque is an effective measure of osseointegration and, experimentally, is usually done in rabbits after the animal is sacrificed (Figure $4 \mathrm{~b}$ ). Removal torque values are shown in Tables 2 and 3 , in which as-machined, acid etched and anodized cpTi implants are compared. In Figure 4, the measured torque is near 50 N.cm for the as-machined implant and increases to $83 \mathrm{~N} . \mathrm{cm}$ for the anodized condition ${ }^{29}$.

Figure 5 shows the typical surface of cpTi implants. The acid etched surface, Figure 5a, displays microroughness $(\sim 1 \mu \mathrm{m})$, which enhances platelet activation and aggregation as well as fibrin retention. A roughened surface plays an important role, not only in osteoblastic attachment, cell differentiation and matrix production, but also in the production of cytokine and growth factor. The anodized surface, seen in Figure 5b, shows an interesting pattern consisting of minivolcanoes and holes that assist cell attachment. This surface contains rutile and anatase, as previously described. Comparing results, that both types of roughened surfaces, etched in Figure 5a and anodized in Figure 5b, significantly enhance bone/implant contact and new bone formation close to the implant, as measured by the removal torque, when compared with machined smooth surfaces ${ }^{29}$.

\subsection{Performance evaluation}

Dental implant osseointegration and stability is commonly evaluated by the removal torque which is an indicative of the secondary stability achieved after the healing period. There is a way to correlate the removal torque ${ }^{29,38}$, which is an external measurement dependent on the geometry of the implant, to 


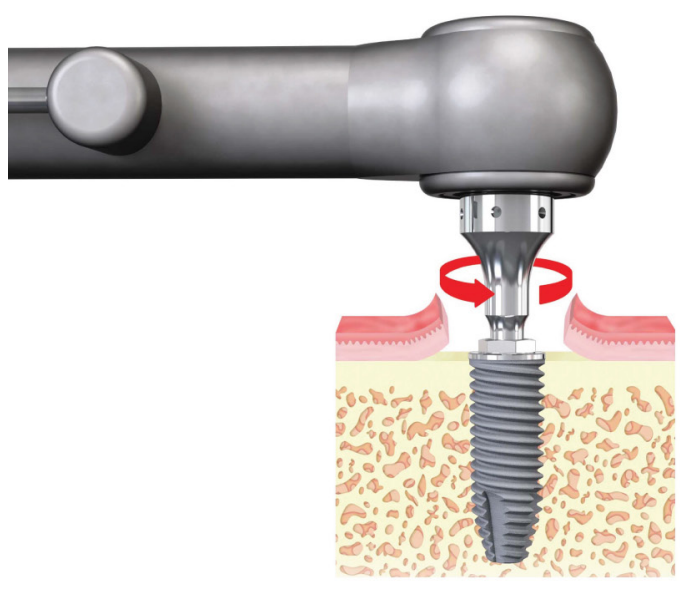

(a)

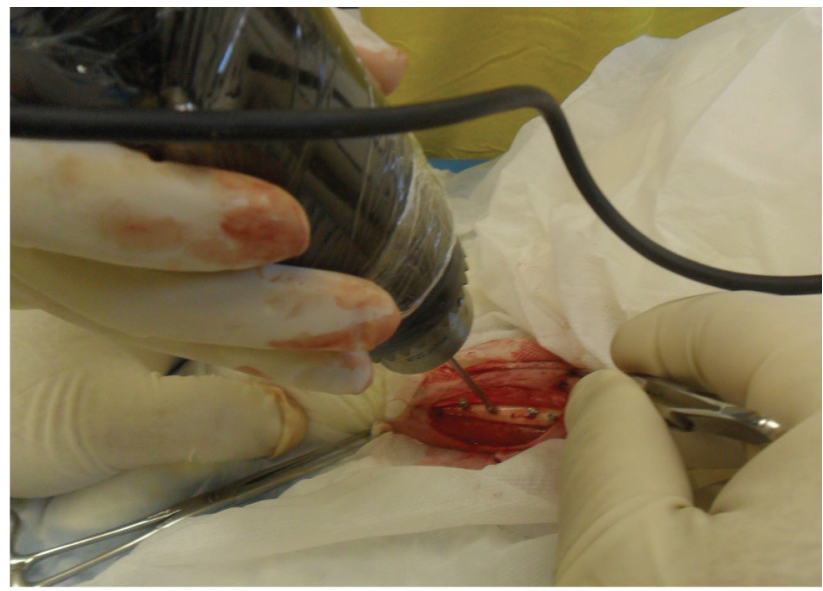

(b)

Figure 4. Scheme of (a) implant placement and (b) removal torque measurement on miniscrews placed in tibiae of rabbits.

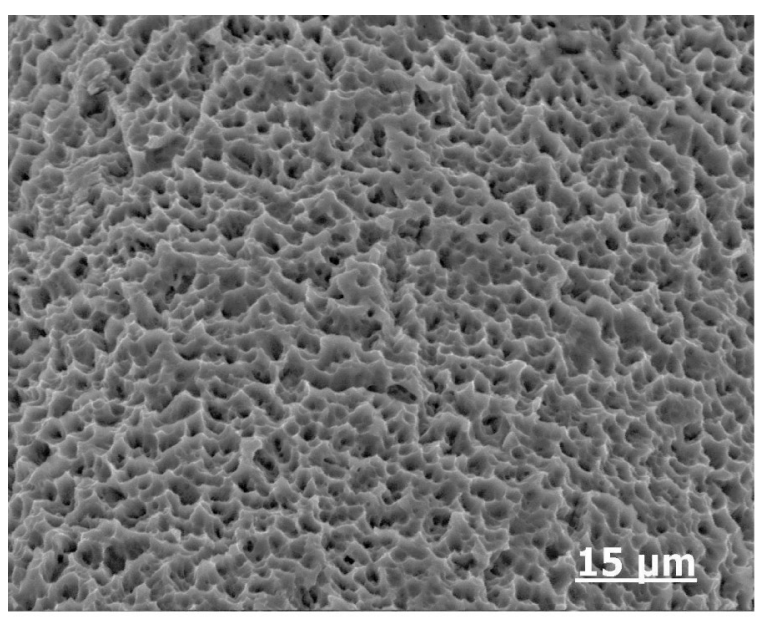

(a)

Figure 5. Surfaces of (a) acid etched and (b) anodized cp titanium.

the intrinsic shear strength of the bone/implant interface. The shear stress $\tau$ acting on the interface is proportional to the applied torque and inversely proportional to the implant area. The implant area can be calculated using a computer software such a SolidWorks. Equation 1 shows the dependence of the shear stress $\tau$ on torque (T) and implant dimensions (diameter D and area A).

$\tau=\frac{2 T}{D A}$

In order to increase the mechanical stability of the implant during insertion and reduce the stresses in the bone/implant interface during mastication it is strongly recommended to keep stress below $60 \mathrm{~N} / \mathrm{mm}^{2}$ increasing, if necessary, the implant surface ${ }^{39}$. Increasing the diameter and length of an implant enhances bone/implant contact, but due to space constraints and a limited amount of bone in the jaw, the surgeon has to face severe limitations in both paramerts. Therefore, in order to keep the load as low as possible, implant design and thread shape are changed and a surface treatment is carried out.

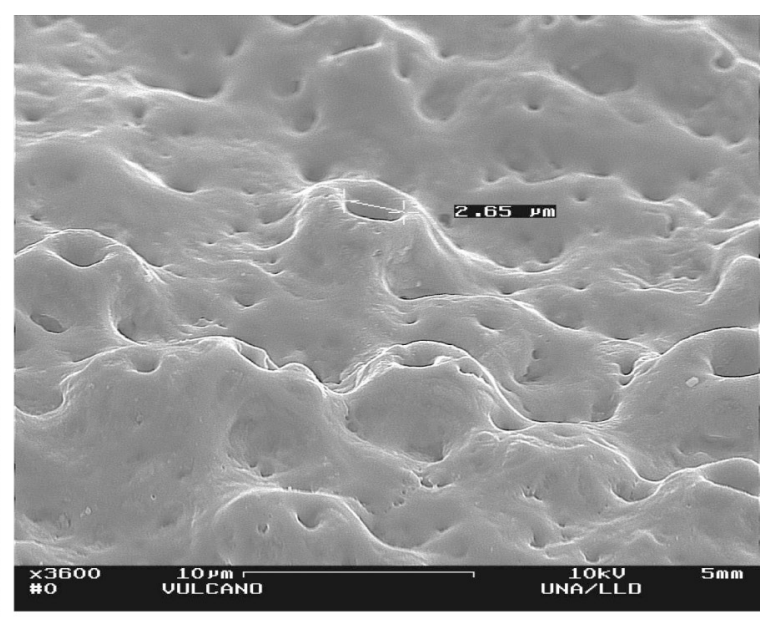

(b)

Table 2. Dental implant removal torque after 8 weeks inserted in rabbit's tibia ${ }^{1}$.

\begin{tabular}{cc}
\hline Titanium implant & $\begin{array}{c}\text { Removal Torque } \\
\text { (N.cm) }\end{array}$ \\
\hline cpTi ASTM grade 2 & $17.0 \pm 4.2$ \\
UFG Ti grade 2 & $18.9 \pm 1.9$ \\
\hline
\end{tabular}

Table 3. Dental cpTi implants removal torque from tibia of rabbits ${ }^{29}$.

\begin{tabular}{cc}
\hline Titanium implant & $\begin{array}{c}\text { Removal Torque } \\
\text { (N.cm) }\end{array}$ \\
\hline Machined & $57.0 \pm 18.6$ \\
Acid etched & $75.4 \pm 10.5$ \\
Annodized & $83.1 \pm 12.7$ \\
\hline
\end{tabular}

\section{Design of Dental Implants}

Dental implant designs are constantly altered by manufacturers in order to attain a large bone-implant contact area (Figure 6). There are several geometric shapes and surface properties (morphology, roughness, wettability, 


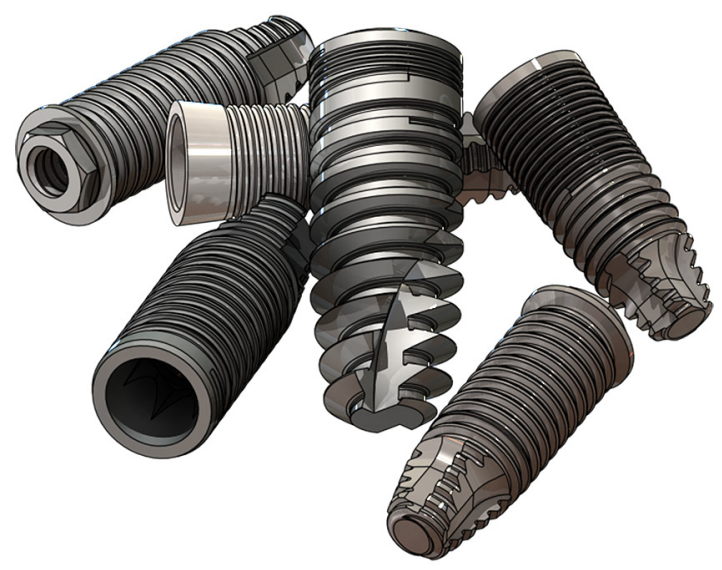

Figure 6. Dental implants with different shapes.

oxide layer thickness, oxide type, impurity level) that can be engineered to improve the implant performance regarding osseointegration and reduction of stress concentration close to the cervical area ${ }^{29}$.

Efforts to achieve a better interaction between bone and implant include improvements of primary stability based on the optimization of force distribution. Most dental implants are screw-shaped, with rounded threads, because they provide a large contact area, an adequate primary stability, a low shear stress at the bone-implant interface a low stress concentration $^{28}$.

Mechanical strength and stiffness are very important factors for the long-term use of Ti and its alloys in implants for biomedical applications ${ }^{2,40}$ Table 1 shows the ASTM requirements of commercially pure Ti bars for dental implants and the corresponding properties of Tigrade 5 (Ti-6Al-4V alloy) as well as the different types of UFG Ti and bone.

Sometimes, the load transfer from the implant to the bone may result in bone reabsorption and consequent loosening of the implant. Bone remodeling caused by stress leads to changes in bone density and geometry. The formation of microcracks through fatigue damage may be an additional stimulus for bone remodeling, which alternates bone resorption and apposition ${ }^{41}$.

Loosening of dental and orthopaedic implants happens when the device damages the host bone faster than the bone cells can repair. In other words, the mechanisms of bone remodeling have not enough time to remove damaged bone and replace it with new bone ${ }^{39}$.

According to Wolff' law, changes in the form and function of bone results in modifications in its internal and external architecture and is ruled by mathematical laws $\mathrm{s}^{39,42}$. For analytical purposes, the bone can be split in small units called basic multicellular units (BMUs) that replace old bone with a new one. The best known model of a basic structure unit is the secondary Haversian system, which is able to turn over around $.010-.013 \mathrm{~mm}^{3}$ per month ${ }^{42}$.

Implant materials with low elastic moduli have better stress distribution at the implant-bone interface and cause less bone atrophy. A large difference between the moduli of elasticity of the implant material and the bone can induce stress shielding, i.e. insufficient transfer of stress to the bone.
The mechanical strength of implants is important, but they must also be somewhat flexible to avoid shielding the bones from stress. To understand the stressshielding phenomenon, it is necessary to understand that the human body tends to reduce or eliminate their own parts when they are not used. The muscle mass, for instance, is increased by exercise; when we do not exercise, our muscles are gradually lost. Stress shielding is a process that occurs when the forces exerted on a member with a prosthesis are different from the forces applied to a normal limb. This difference induces the loss of bone density at the site (osteopenia), leading to bone atrophy. A common site for stress shielding is the proximal femoral diaphysis after placement of a femoral prosthesis. The more tightly the stem of the prosthesis fits into the distal medullary canal, the greater the shift of body weight to the prosthetic stem from the proximal femoral cortex. This causes loss of the normal remodeling forces above the level at which the stem is fixated against the endosteal surface of the medullary canal, resulting in osteopenia of the proximal femoral diaphysis ${ }^{43}$. This can potentially lead to bone loss in the long term and eventual loosening of the device, requiring an early revision surgery ${ }^{44}$.

Besides the relation between stress-shielding and bone resorption, other factors can interfere in the bone remodeling process $^{42}$. Humoral factors include vitamins, minerals, drugs and hormones, while cell-biologic factors are related to angiogenesis, apoptosis, cellular pumps, gene expression patterns and also cytokines, growth factors and several other ligand elements ${ }^{39}$.

Bone tissue is hierarchically organized in an anisotropic, irregular, optimized structure divided in different levels, including a subnanostructure composed of molecular arrangements of minerals, type I collagen, water and non-collagenous organic proteins. Further hierarchical stages, consist of nanostructures composed by fibrillar collagen embedded in mineral material; submicrostructures assembled by lamellae; microstructures containing the Harvesian system, osteoms, single trabeculae; and, finally, macrostructures formed by components with different structures governed by environmental stimuli ${ }^{45-48}$.

Morphologically, the bone macrostructure is divided into two types: trabecular bone and compact bone. The differences are both structural and functional, since both have the same matrix composition. Trabecular bone, also called cancellous or spongy bone, consists of interconnecting plates and rods of tissue that form an interconnected, open-celled porous structure. Compact bone also called cortical or osteonal bone, is denser than trabecular bone. Trabecular bone is much more active metabolically than cortical bone. Consequently, it is remodeled more often, and thus younger, than cortical one $^{47}$. The type of bone present at the implant site is a very important factor for the success of dental implants.

$\mathrm{Mish}^{49}$ defined four types of bone in the human jaw. Type I bone is composed of homogeneous compact bone; Type II has a thick layer of compact bone surrounding a core of dense trabecular bone; Type III bone has a thin layer of cortical bone surrounding a core of dense trabecular bone; and type IV bone has a thin layer of cortical bone surrounding a core of low-density trabecular bone. An implant placed in poor quality bone (Type IV bone) is more likely to fail than implants placed in the other types of bones. When compared 
to the maxilla, clinical reports have indicated a higher survival rate for dental implants in the mandible, particularly in the anterior region of the mandible, which has been associated with better volume and density of the bone. Consequently, factors such as bone quality and quantity determine the procedure and the type of implant.

Unfortunately, the bone surrounding a dental implant is sometimes lost. If a dental implant is overloaded, this can cause loss of the bone surrounding the dental implant. Frost ${ }^{42}$ reported that the maximum strain supported by a bone cell unit is around 2000 and 4000 microstrains ( $\mu$ strain) while the largest safe strain peak is around $1500 \mu$ strain. Above $4000 \mu$ strain, the microdamage is too high to be repaired, resulting in an accumulation of damaged cells that can lead to failure of the trabecular bone. Simply doubling the amount of strain can multiply the microdamage by a factor of hundreds. In most cases, bone loss starts at the top of the bone (crest) leading to stress shielding due to loss of contact at the implant neck and bone resorption progresses around the dental implant to form a saucer type defect ${ }^{41}$. It would be worthwhile to investigate possible factors that reduce bone loading. The geometry of implant is an important factor to control, especially when it is considered that even in the most adverse conditions of bone support, bone loss is larger during the first three years after implant placement. The overload resorption occurred in elements covering the first threads, close to the implant neck ${ }^{41}$.

The standard ISO/DIS 14801 (Dentistry - Dynamic fatigue test for endosseous dental implants) $)^{50}$ is useful for comparing endosseous dental implants of different designs and sizes. This mechanical test simulates the functional loading of an endosseous dental implant and its premanufactured prosthetic components under "worst case" conditions. The worst case is that of a small implant clamped with axis making an angle of $30^{\circ} \pm 1^{\circ}$ with the loading direction of the testing machine, as shown in Figure 7.

In some cases, the surgeon must insert the implant in a region of the jaw with a small thickness of cortical bone. Due to limitation of the mechanical properties of cpTi, the implant must have a diameter of at least $3.2 \mathrm{~mm}$. In order to solve this problem, manufacturers normally change the shape of the implant and of the prosthetic connection. Examples are shown in Figure 8 for conical and cylindrical implants. Miniscrews (Figure 9) are also applied, but only temporarily. They have no osseointegration behavior, small length $(6 \mathrm{~mm})$, small diameter $(1.5 \mathrm{~mm}$ - Figure $9 \mathrm{a})$ and generally have self-drilling threaded screws (Figure 9b, c) ) $^{38}$. The use of UFG cpTi for biomedical purposes could fill this gap and the performance of this alloy might be evaluated for this purpose. The behavior of this alloy is presented below.

\section{Ultrafine Grained Titanium}

\subsection{Relevance as a biomaterial}

One of the stimuli for the development of UFG Ti to replace conventional Ti-6Al-4V alloy in dental implants is the presence of alloying elements in the latter that could be toxic when released into the surrounding tissues ${ }^{48,49}$. The UFG material keeps the advantages of cpTi concerning corrosion resistance, biocompatibility and osseointegration

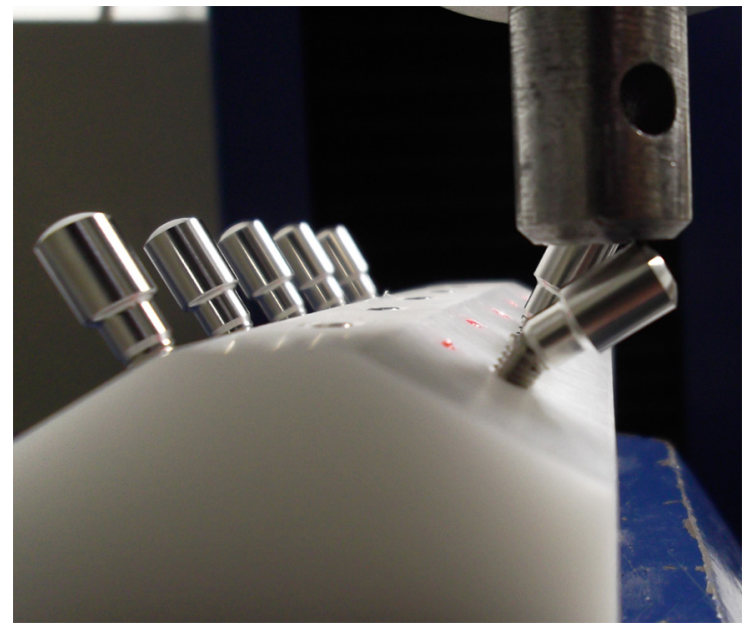

Figure 7. Set up for compression and fatigue test simulating the functional loading of an endosseous dental implant body under critical condition according to standard ISO $14801^{50}$.

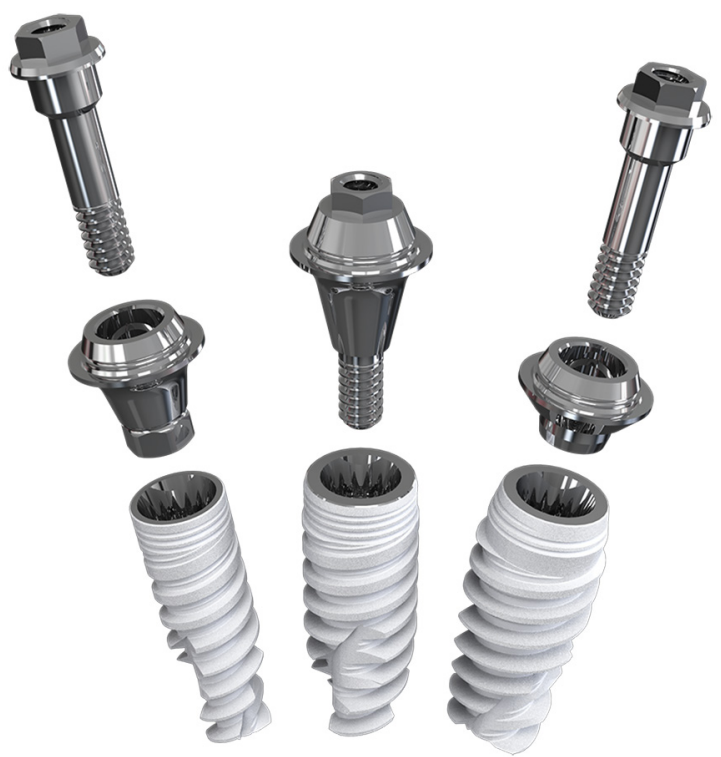

Figure 8. Conical and cylindrical prosthetic connections for dental implants.

and, at the same time, achieves strength levels comparable to those of Ti alloys thanks to the use of the SPD (Severe Plastic Deformation), Figure 10, for grain refinement $t^{3-6,51-59}$.

\subsection{SPD processing}

One of the most successful processing routes for grain size reduction is a special mechanical work called SPD (severe plastic deformation) which is described elsewhere $8,17,54,60-64$. The method also known as Equal-Channel Angular Pressing (ECAP) $)^{5,6,8,51,60,64}$. A limitation of this technique is the need of several passes. A sample has to be reinserted into the die several times, since the shear strain per pass is only on the order of 1 and strains of 4 to 6 are required to generate equiaxed grains with submicrometer sizes. One way to overcome this difficulty by high pressure torsion (HPT), which can generate strains as high as 15 in a single twisting 
operation. However, HPT is presently limited to small samples and the technique has been primarily used as a research tool. Thus, efforts at developing a continuous processing method have been intense.

Two new approaches are gaining wide acceptance. The first is cumulative roll bonding, where a sheet is rolled, folded and re-rolled until a high strain is achieved. The other technique, developed by Valiev et al. ${ }^{65}$, is called ECAP-Conform and uses the principle of ECAP in a cylindrical roll. In this process, a rod is inserted into the cylinder between guides, undergoing the ECAP process on its way out. In this manner, long rods can be produced. This technique is amenable to industrial scale production in rod geometry, well suited for dental implants. For additional information on this technique and other SPD methods, the reader is referred to the work of Valiev \& Langdon ${ }^{64}$.

\subsection{Microstructure}

SPD processing of cpTi is an effective way to produce an UFG structure ${ }^{51,54,60,65-68}$. Figure 10a shows a TEM micrograph of UFG Ti obtained by ECAP-Conform with equiaxed morphology with grain/subgrain sizes between 150 and $200 \mathrm{~nm}$. For the sake of comparison, Figure 10b show the micrograph of a Ti-6Al-4V alloy used for biomedical purposes. The ultrafine structure is produced by the breakup of the original grain microstructure and by successive rotation of the subgrains into new grains (nanosized) by the increase in angular misorientation between adjacent grains.

In the case of a VT1-0 (Russian) cpTi processed at room temperature by HPT under $5 \mathrm{GPa}$ of pressure with ( 5 revolutions) strain of about 7, a ultrafine-grained structure with mean grain size of about $120 \mathrm{~nm}$ is formed. After annealing above $200{ }^{\circ} \mathrm{C}$, a rearrangement of defects promotes high angle grain boundaries with very high dislocation densities, above $10^{14} / \mathrm{cm}^{2}$, which indicates the non-equilibrium character of such grain boundaries after annealing ${ }^{69}$.

In another case of UFG Ti grade 4 produced by four-pass ECAP, which was then processed by forge-drawing at $300{ }^{\circ} \mathrm{C}$ (TMT), the ultimate strength increased from 700 to $1240 \mathrm{MPa}^{[70]}$. An additional isothermal straining at $450{ }^{\circ} \mathrm{C}$ of the previous (ECAP + TMT) UFG Ti, enhanced both the strength, up to $1420 \mathrm{MPa}$, and the ductility, up to $12 \%$. As shown in Figure 11, the warm straining transforms the grains from (a) elongated to (b) equiaxed with mainly high-angle boundaries.

\subsection{Mechanical properties}

As far as the use of UFG Ti as a substitute for cpTi in biomedical applications, the most important properties are those related to mechanical performance. As a result of grain size reduction to nanometric values (Figure 10), the strength of the distinct grades, 1 to 4 , of cpTi is significantly improved by SPD processing, as shown in Table $1^{70-73}$. In this table, it should be noted that marked increases in both the yield and the ultimate strength of cpTi have been achieved through special processing involving not only multiple passes (ECAP) but also annealing and isothermal straining. Indeed, non-alloyed SPD titanium such as UFG Ti grade 4 TMT plus $350^{\circ} \mathrm{C}$ annealing and $450{ }^{\circ} \mathrm{C}$ isothermal straining may reach a strength $(1430 \mathrm{MPa})$ much superior to that of the

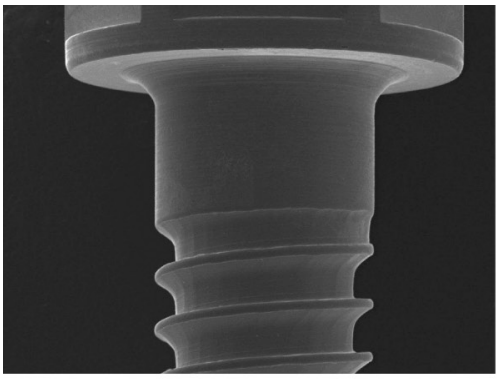

(a)

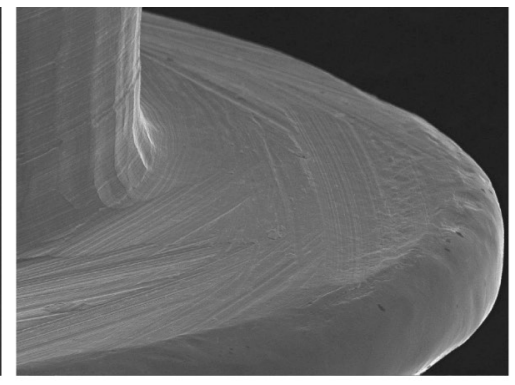

(b)

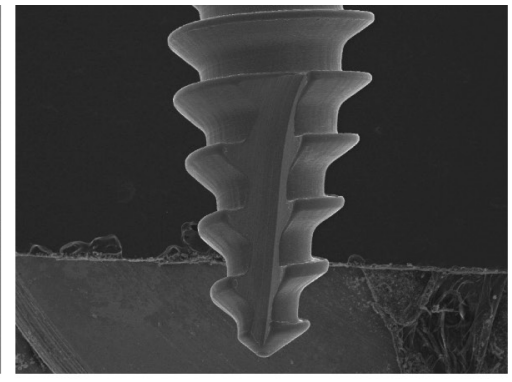

(c)

Figure 9. Ti-6Al-4V self-drilling miniscrews for temporary use. It has reduced length $(6 \mathrm{~mm})$, (a) diameter $(1.5 \mathrm{~mm})$ and threads/tip $(\mathrm{b}, \mathrm{c})$ for self-drilling attachment.
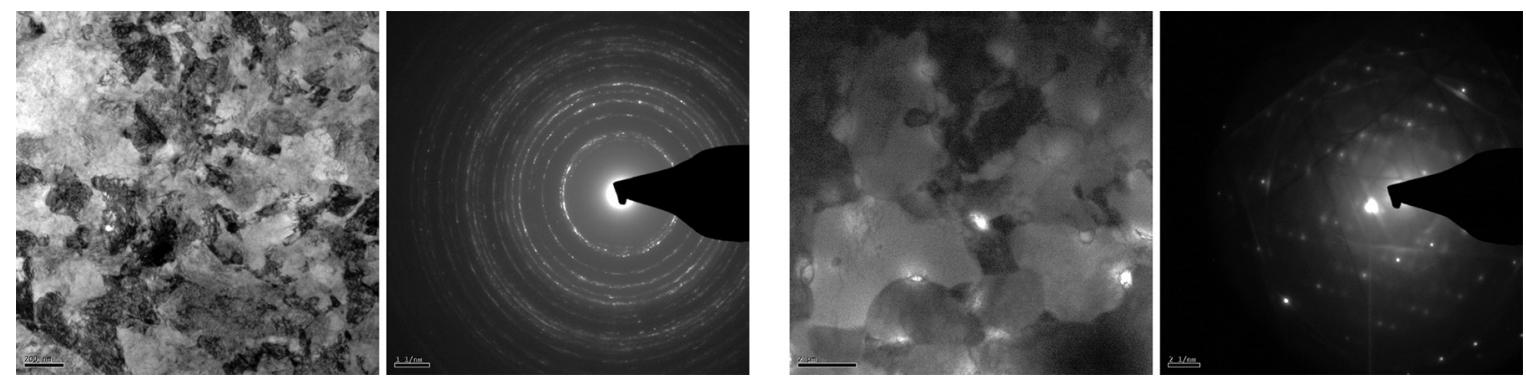

Figure 10. Microstructure of UFG Ti grade 4 with equiaxed grains between 150-200 ๆm (left) and common Ti grade 5 (Ti-6Al-4V) with grains ranging from $2-4 \mu \mathrm{m}$ (right). 

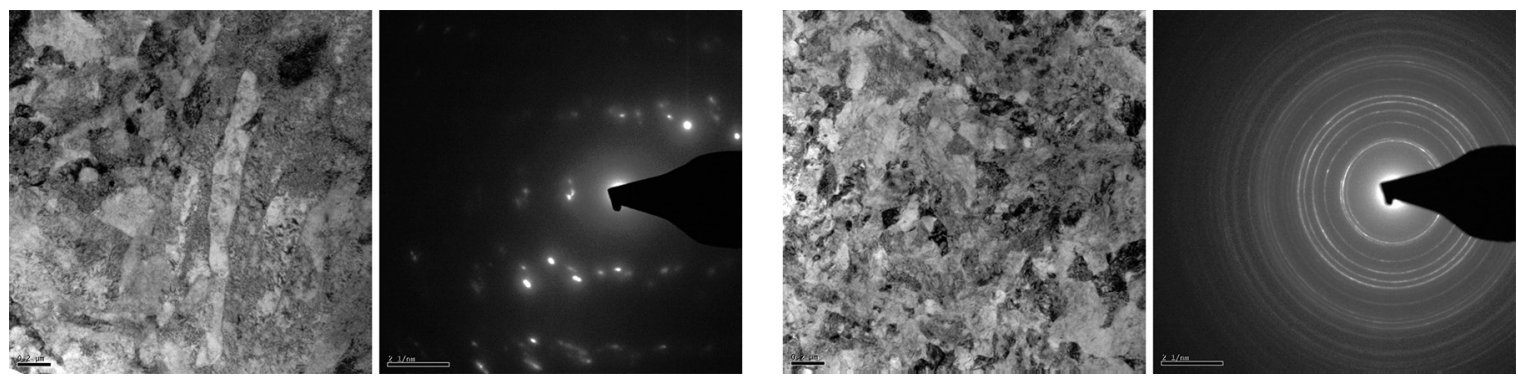

Figure 11. UFG Ti grade 4 produced by four passes ECAP processed by forge-drawing at $300{ }^{\circ} \mathrm{C}$. Microstructure shows elongated (left) and equiaxed with mainly high-angle boundaries (right) after additional isothermal straining at $450{ }^{\circ} \mathrm{C}$ warm.

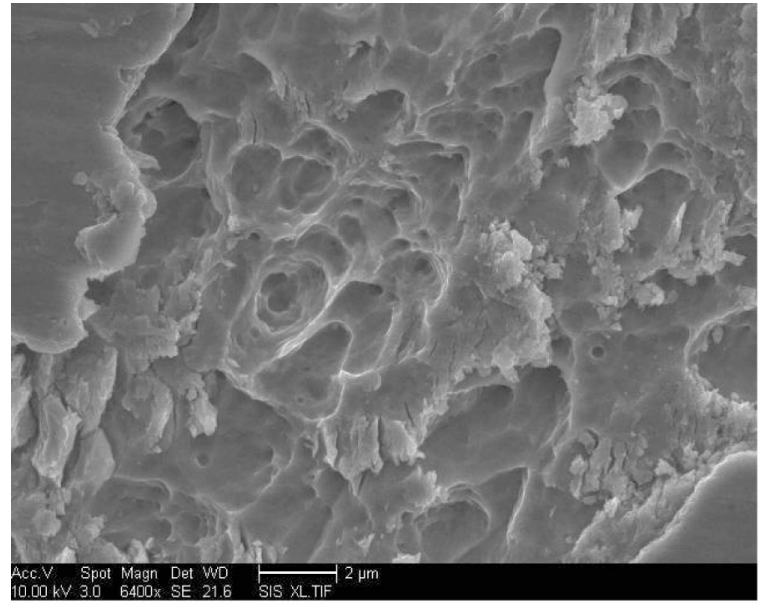

(a)

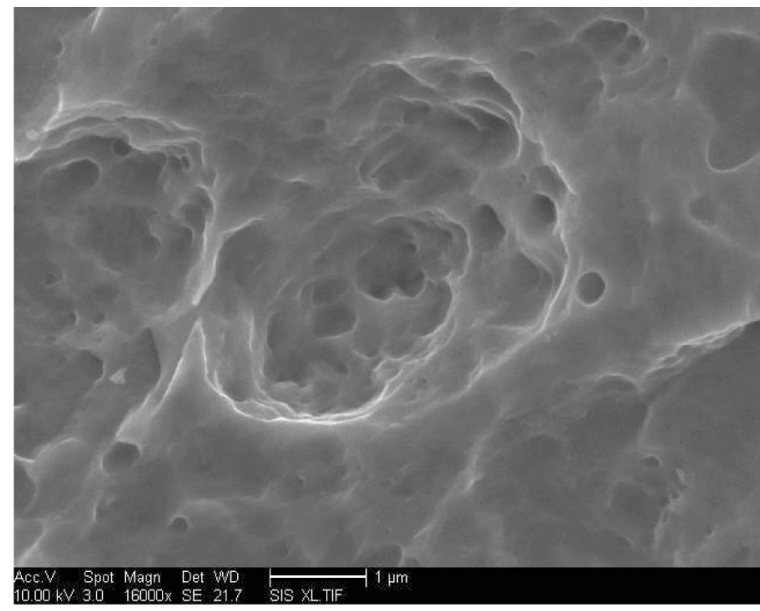

(b)

Figure 12. Surface of (a) acid etched UFG cpTi. Morphology details exhibit (b) intercommunicated microcavities ranging from $0.2-0.5 \mu \mathrm{m}$ in-diameter.

Ti-6Al-4V alloy commonly used in dental implants, which is of the order of $860 \mathrm{MPa}$.

\subsection{Acid etching UFG implants}

Acid etching of dental implants is a technique which depends on several factors such as reagent concentration, temperature and time. Usually, the treatment is performed using an aqueous solution of $\mathrm{HCl}, \mathrm{H}_{2} \mathrm{SO}_{4}, \mathrm{HNO}_{3}$ or $\mathrm{HF}$. When etching is performed with $\mathrm{HNO}_{3}$, the titanium oxide layer is passivated ${ }^{28}$. Figure 12 a shows the surface morphology of UFG cpTi after etching.

Etching is used to produce a surface with micro and nanoroughness in order to improve protein adsorption and cell adhesion. The surface morphology shown in Figure 12b is isotropic and exhibits intercommunicated microcavities (0.2-0.5 $\mu \mathrm{m}$ in-diameter) with nanoscale roughness on the walls. This topography should be efficient for absorption of the bioproteins that trigger fhe osseointegration process.

\subsection{In vivo experiments}

In order to determine the degree of osseointegration, cpTi and UFG Ti machined mini-implants without surface treatment were inserted in New Zealand rabbits (Figure 13). The Institutional Ethical Committee for Animal Care approved the experiment. Temporary implants were loaded to stimulate

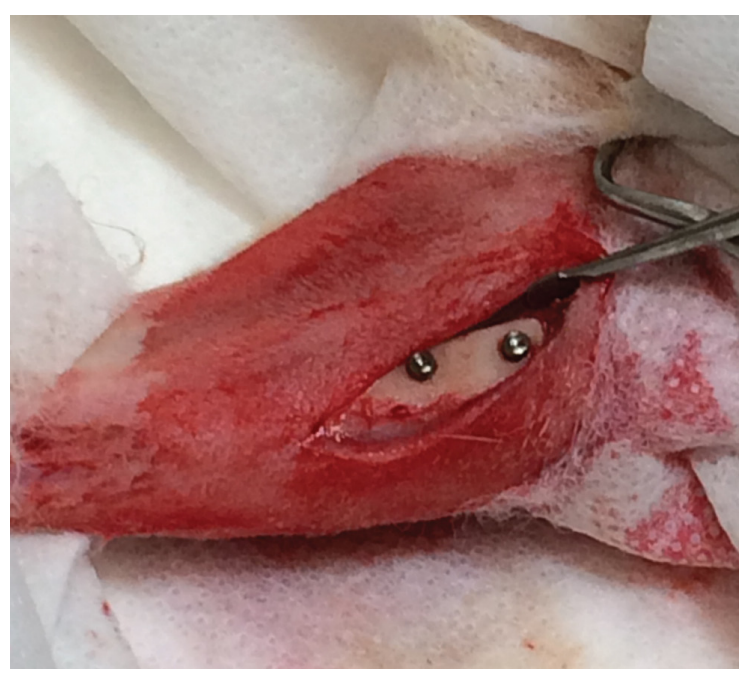

Figure 13. Two reduced size UFG cp implants with acid etched surface placed in tibiae of rabbits.

the bone-implant interface. This was done by attaching two implants through a loaded NiTi spring and keeping the implants for 8 weeks. Subsequent to the sacrificing of the animals, the removal torques was measured. The results are shown in Table 2. The UFG implants had a removal torque 


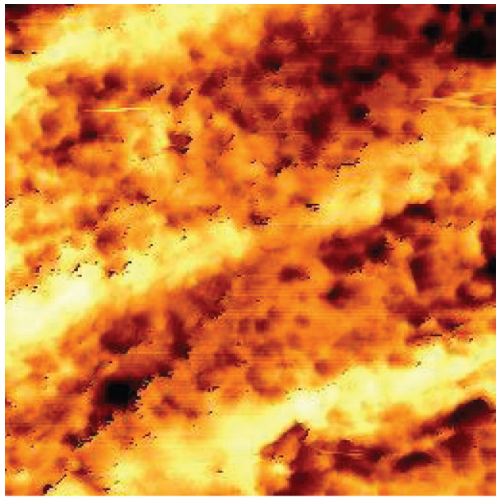

(a)

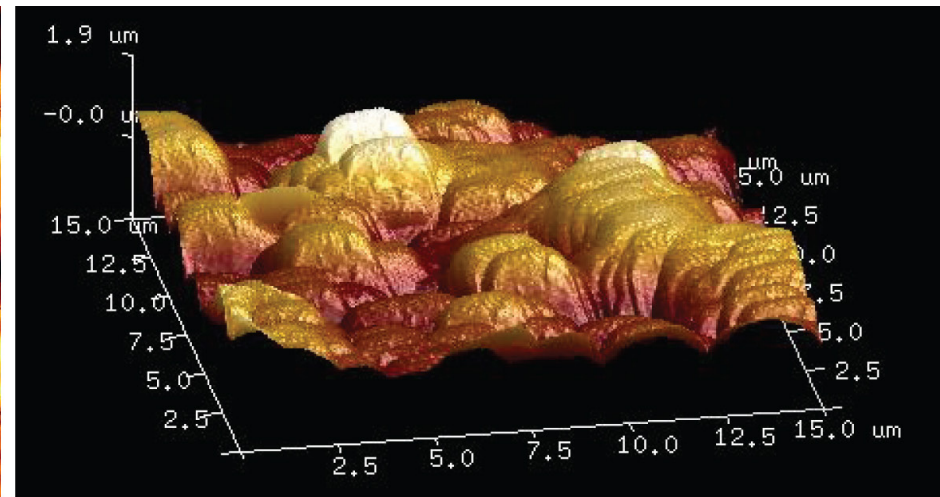

(b)

Figure 14. AFM images of acid etched UFG titanium. (a) 3D map of titanium surface for approximately $15 \mu \mathrm{m} \times 15 \mu \mathrm{m}$ scanning area (b) Surface morphology of the UFG etched titanium.

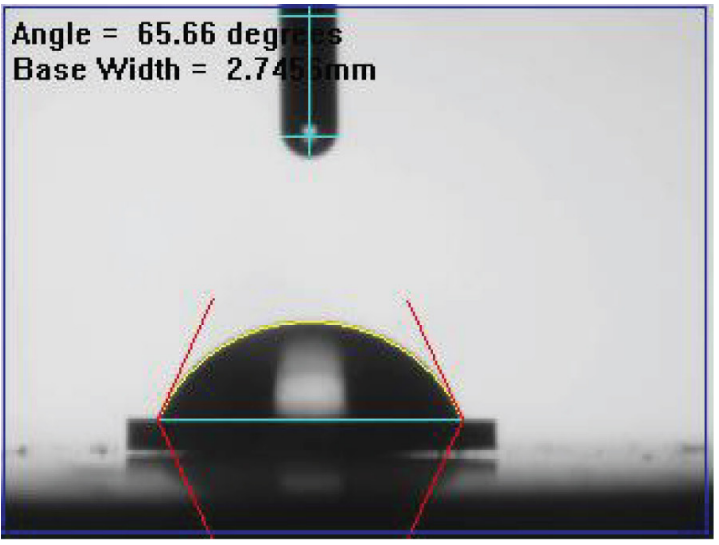

(a)

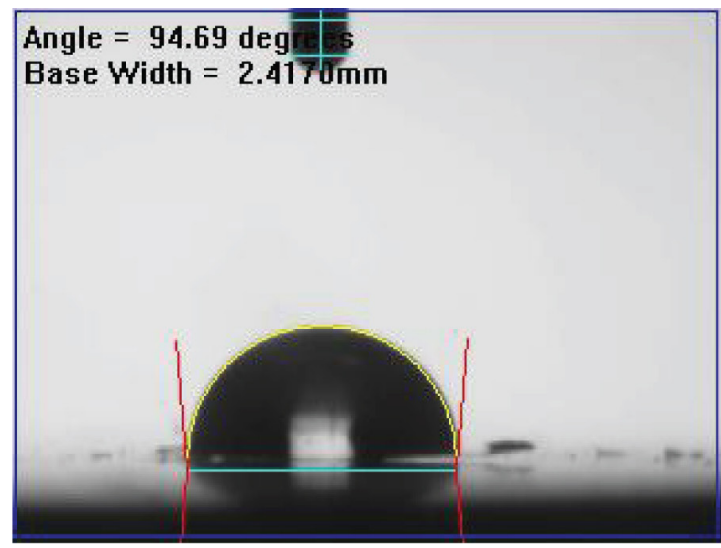

(b)

Figure 15. Contact angle of (a) UFG and (b) coarse grain titanium grade 4.

of 18.9 N.cm, which is slightly higher than that of implants made of commercially available cpTi. Thus, the UFG structure resulted in a modest osseointegration improvement ${ }^{1}$.

Nie et al. ${ }^{36}$ reported promising features of UFG titanium. They analyzed the performance of the material under in vitro and in vivo tests, and found that UFG Ti was better than cpTi with regard to bioactivity, stability and cellular functionalization.

The nanostructured surface modulates gene expression and induces cellular response by mimicking the extracellular matrix of the host bone.

As in etched conventional Ti for biomedical applications, etched UFG surfaces were rougher than without surface treatment (Figure 14). The roughness was measured using atomic force microscopy (AFM) in an area of $15 \times 15 \mu \mathrm{m}^{2}$ (Figure $14 \mathrm{a})$. The average roughness $(\mathrm{Ra})$ increased from $76.7 \eta \mathrm{m}$ to $415 \eta \mathrm{m}$ and the rms value increased from $98.4 \mathrm{\eta m}$ to $526 \eta \mathrm{m}$ (Figure 14b).

Regarding wettability, UFG titanium shows enhanced hydrophilicity (Figure 15a), with a lower contact angle $\left(65.66^{\circ} \pm 2.28\right)$ than cpTi (Figure $\left.15 b\right)\left(92.68^{\circ} \pm 1.51\right)$. This is attributed to the fact that the grain size of UFG titanium is significantly smaller, increasing the surface energy and thus the wettability of the grains. Higher wettability of the nanostructured material may also affect the absorption of proteins $^{74}$. In many cases, intertaction of a nanostructured material with host macromolecules initiate inflammatory or immune responses and then repair or regeneration that facilitates osseointegration.

\section{Concluding Remarks}

Beyond the remarkable mechanical properties of UFG cpTi, the significantly smaller grain size of the material can induce favorable biological responses. Exceptional improvements were seen in surface topography (micro and nanoroughness), wettability and in the homogeneity of the oxide layer. The overall enhancement in mechanical performance means that this material can be used in most biomedical applications of the conventional Ti-6Al-4V alloy, with the advantage of avoiding the risk of releasing toxic metallic ions. Moreover, etched UFG seems to offer a good combination of biocompatibility and adequate mechanical behavior. The microstructure improvements provided by the ECAP technique coupled with surface etching, described in this work, can result in an outstanding performance of cpTi alloy for biomedical applications. 


\section{Acknowledgements}

We thank professor Ronaldo de Biasi (Military Institute of Engineering) for reading and considerably improving the manuscript; Carlos Chagas Foundation for Research

\section{References}

1. Elias CN, Lima JHC, Valiev RZ and Meyers MA. Biomedical applications of titanium and its alloys. JOM. 2008; 60(3):46-49. http://dx.doi.org/10.1007/s11837-008-0031-1.

2. Williams DF. On the mechanisms of biocompatibility. Biomaterials. 2008; 29(20):2941-2953. http://dx.doi.org/10.1016/j. biomaterials.2008.04.023. PMid:18440630.

3. Semenova IP, Salimgareeva GK, Latysh VV, Lowe T and Valiev RZ. Enhanced fatigue strength of commercially pure Ti processed by severe plastic deformation. Materials Science and Engineering A. 2009; 503(1-2):92-95. http://dx.doi.org/10.1016/j. msea.2008.07.075.

4. Vinogradov AY, Stolyarov VV, Hashimoto S and Valiev RZ. Cyclic behavior of ultrafine-grain titanium produced by severe plastic deformation. Materials Science and Engineering A. 2001; 318(1-2):163-173. http://dx.doi.org/10.1016/S09215093(01)01262-X.

5. Valiev RZ, Semenova IP, Jakushina E, Latysh VV, Rack H, Lowe TC, et al. Nanostructured SPD processed titanium for medical implants. Materials Science Forum. 2008; 584:49-54. http://dx.doi.org/10.4028/www.scientific.net/MSF.584-586.49.

6. Valiev RZ, Semenova IP, Latysh VV, Rack H, Lowe TC, Petruzelka $\mathrm{J}$, et al. Nanostructured titanium for biomedical applications. Advanced Engineering Materials. 2008; 10(8):B15-B17. http:// dx.doi.org/10.1002/adem.200800026.

7. Yan W. Nanocoating for orthopaedic and dental application. In: Zhang S, editor. Nanocomposite thin films and coating: processing, properties and performance. London: Imperial College Press; 2007. http://dx.doi.org/10.1142/97818609499 750011.

8. Valiev RZ. Nanostructuring of metals by severe plastic deformation for advanced properties. Nature Materials. 2004; 3(8):511-516. http://dx.doi.org/10.1038/nmat1180. PMid:15286754.

9. Hench LL, Jones JR, editors. Biomaterials artificial organs and tissue engineering. Cambridge: Woodhead Publishing; 2005.

10. Will J, Gerhardt LG and Boccaccini AR. Bioactive glass-based scaffolds for bone tissue engineering. Advances in Biochemical Engineering/Biotechnology. 2012; 126:195-226. http://dx.doi. org/10.1007/10_2011_106. PMid:22085919.

11. Pozio A, Palmieri A, Girardi A, Cura F and Carinci F. Titanium nanotubes activate genes related to bone formation in vitro. Dental Research Journal. 2012; 9(Suppl 2):S164-S168. PMid:23814577.

12. Faghihi S, Zhilyaev A, Szpunar J, Azari F, Vali H and Tabrizian M. Nanostructuring of a titanium material by high-pressure torsion improves pre-osteoblast attachment. Advanced Materials. 2007; 19(8):1069-1073. http://dx.doi.org/10.1002/adma.200602276.

13. Hamlet S, Alfarsi M, George R and Ivanovski S. The effect of hydrophilic titanium surface modification on macrophage inflammatory cytokine gene expression. Clinical Oral Implants Research. 2012; 23(5):584-590. http://dx.doi.org/10.1111/j.16000501.2011.02325.x. PMid:22093029.

14. Dadsetan M, Jones JA, Hiltner A and Anderson JM. Surface chemistry mediates adhesive structure, cytoskeletal organization, and fusion of macrophages. Journal of Biomedical Materials Research. 2004; 71(3):439-448. http://dx.doi.org/10.1002/ jbm.a.30165. PMid:15476262.
Support from the Rio de Janeiro State (FAPERJ) and Capes Foundation from Brazilian Government for support this investigation by the grants: E-26/102.766/2012 and BEX $539012-5 / 2013$.

15. Kokubo T, Kim HM, Kawashita M and Nakamura T. Bioactive metals: preparation and properties. Journal of Materials Science: Materials in Medicine. 2004; 15(2):99-107. http:// dx.doi.org/10.1023/B:JMSM.0000011809.36275.0c.

16. Menezes GC, Elias CN, Attias M and Silva FC Fo. Osteoblast adhesion onto titanium dental implants. Acta Microscopica. 2003; 12(1):13-19.

17. Valiev RZ, Islamgaliev RK and Alexandrov IV. Bulk nanostructured materials from severe plastic deformation. Progress in Materials Science. 2000; 45(2):103-189. http://dx.doi.org/10.1016/S00796425(99)00007-9.

18. Brånemark PI, Hansson BO, Adell R, Breine U, Lindström J, Hallén $\mathrm{O}$, et al. Osseointegrated implants in the treatment of the edentulous jaw. Experience from a 10-year period. Scandinavian Journal of Plastic and Reconstructive Surgery. 1977; 16:1-132. PMid:356184.

19. Truong VK, Lapovok R, Estrin YS, Rundell S, Wang JY, Fluke $\mathrm{CJ}$, et al. The influence of nano-scale surface roughness on bacterial adhesion to ultrafine-grained titanium. Biomaterials. 2010; 31(13):3674-3683. http://dx.doi.org/10.1016/j. biomaterials.2010.01.071. PMid:20163851.

20. Estrin Y, Ivanova EP, Michalska A, Truong VK, Lapovok R and Boyd R. Accelerated stem cell attachment to ultrafine grained titanium. Acta Biomaterialia. 2011; 7(2):900-906. http://dx.doi. org/10.1016/j.actbio.2010.09.033. PMid:20887818.

21. Handtrack D, Sauer C and Kieback B. Microstructure and properties of ultrafine-grained and dispersion-strengthened titanium materials for implants. Journal of Materials Science. 2008; 43(2):671-679. http://dx.doi.org/10.1007/s10853-0072160-2.

22. Saitova LR, Höppel HW, Göken M, Semenova IP, Raab GI and Valiev RZ. Fatigue behavior of ultrafine-grained Ti-6Al4V 'ELI' alloy for medical applications. Materials Science and Engineering A. 2009; 503(1-2):145-147. http://dx.doi. org/10.1016/j.msea.2008.04.082.

23. American Society for Testing and Materials - ASTM. ASTM F67-13: standard specifications for unalloyed titanium, for surgical implant applications. West Conshohocken: ASTM; 2013.

24. Chen $Y$ and Webster TJ. Increased osteoblast functions in the presence of BMP-7 short peptides for nanostructured biomaterial applications. Journal of Biomedical Materials Research. Part A. 2009; 91(1):296-304. http://dx.doi.org/10.1002/jbm.a.32246. PMid:18980196.

25. Maitz MF, Pham MT, Wieser E and Tsyganov I. Blood compatibility of titanium oxides with various crystal structure and element doping. Journal of Biomaterials Applications. 2003; 17(4):303-319. http://dx.doi.org/10.1177/0885328203 017004005. PMid:12797422.

26. Drnovsek N, Daneu N, Recnik A, Mazaj M, Kovac J and Novak S. Hydrothermal synthesis of a nanocrystalline anatase layer on Ti6A4V implants. Surface and Coatings Technology. 2009; 203(10-11):1462-1468. http://dx.doi.org/10.1016/j. surfcoat.2008.11.031.

27. Adamek G and Jakubowicz J. Microstructure of the mechanically alloyed and electrochemically etched $\mathrm{Ti}-6 \mathrm{Al}-4 \mathrm{~V}$ and $\mathrm{Ti}-$ $15 \mathrm{Zr}-4 \mathrm{Nb}$ nanocrystalline alloys. Materials Chemistry and 
Physics. 2010; 124(2-3):1198-1204. http://dx.doi.org/10.1016/j. matchemphys.2010.08.057.

28. Elias CN. Factors affecting the success of dental implants. In: Turkyilmaz I. Implant dentistry: a rapidly evolving practice. New York: In Tech; 2011. p. 319-364.

29. Elias CN and Meirelles L. Improving osseointegration of dental implants. Expert Review of Medical Devices. 2010; 7(2):241256. http://dx.doi.org/10.1586/erd.09.74. PMid:20214429.

30. Schliephake H, Aref A, Scharnweber D, Bierbaum S, Roessler S and Sewing A. Effect of immobilized bone morphogenic protein 2 coating of titanium implants on peri-implant bone formation. Clinical Oral Implants Research. 2005; 16(5):563-569. http:// dx.doi.org/10.1111/j.1600-0501.2005.01143.x. PMid:16164462.

31. Shah JS, Venkatsurya PKC, Thein-Han WW, Misra RDK, Pesacreta TC, Somani MC, et al. The role of nanocrystalline titania coating on nanostructured austenitic stainless steel in enhancing osteoblasts functions for regeneration of tissue. Materials Science and Engineering: C. 2011; 31(2):458-471. http://dx.doi.org/10.1016/j.msec.2010.11.005.

32. Rupp F, Haupt M, Klostermann H, Kim HS, Eichler M, Peetsch A, et al. Multifunctional nature of UV-irradiated nanocrystalline anatase thin films for biomedical applications. Acta Biomaterialia. 2010; 6(12):4566-4577. http://dx.doi. org/10.1016/j.actbio.2010.06.021. PMid:20601247.

33. Bernathova I and Bursak M. Properties of pure titanium and ultra fine grained titanium. Metalurgija. 2011; 50:249-252.

34. Bindu S, Sanosh KP, Smetana K, Balakrishnan A and Kim TN. An in vivo evaluation of ultra-fine grained titanium implants. Journal of Materials Science and Technology. 2009; 25:556-560.

35. Shao H, Yu C, Xu X, Wang J, Zhai R and Wang X. Influence of Ti nanocrystallization on microstructure, interface bonding, surface energy and blood compatibility of surface TiO2 films. Applied Surface Science. 2010; 257(5):1649-1654. http://dx.doi. org/10.1016/j.apsusc.2010.08.116.

36. Nie FL, Zheng YF, Wei SC, Wang DS, Yu ZT, Salimgareeva $\mathrm{GK}$, et al. In vitro and in vivo studies on nanocrystalline $\mathrm{Ti}$ fabricated by equal channel angular pressing with microcrystalline $\mathrm{CP}$ Ti as control. Journal of Biomedical Materials Research. Part A. 2013; 101(6):1694-1707. http://dx.doi.org/10.1002/ jbm.a.34472. PMid:23184756.

37. Kasuga T, Kondo $\mathrm{H}$ and Nogami M. Apatite formation on $\mathrm{TiO} 2$ in simulated body fluid. Journal of Crystal Growth. 2002; 235(14):235-240. http://dx.doi.org/10.1016/S0022-0248(01)01782-1.

38. Morais LS, Serra GG, Muller CA, Andrade LR, Palermo EFA, Elias CN, et al. Titanium alloy mini-implants for orthodontic anchorage: Immediate loading and metal ion release. Acta Biomaterialia. 2007; 3(3):331-339. http://dx.doi.org/10.1016/j. actbio.2006.10.010. PMid:17257912.

39. Frost HM. An update of bone physiology and wolff's law for clinicians. The Angle Orthodontist. 2004; 74(1):3-15. PMid:15038485.

40. Niiomi M. Tend and present state of titanium alloys with body centered structure for biomedical applications. Bulletin of The Iron and Steel Institute of Japan. 2010; 15:661-670.

41. Li J, Li H, Shi L, Fok AS, Ucer C, Devlin H, et al. A mathematical model for simulating the bone remodeling process under mechanical stimulus. Dental Materials. 2007; 23(9):1073-1078. http://dx.doi.org/10.1016/j.dental.2006.10.004. PMid:17137621.

42. Frost HM. Wolff's Law and bone's structural adaptations to mechanical usage: an overview for clinicians. The Angle Orthodontist. 1994; 64(3):175-188. PMid:8060014.

43. Niinomi $M$ and Nakai M. Titanium-based biomaterials for preventing stress shielding between implant devices and bone.
International Journal of Biomaterials. 2011; 2011:836587. PMid:21765831.

44. Cristofolini L and Viceconti M. In vitro stress shielding measurement can be affected by large errors. The Journal of Arthroplasty. 1999; 14(2):215-220. http://dx.doi.org/10.1016/ S0883-5403(99)90129-8. PMid:10065730.

45. Huiskes R, Weinans H and Van Rietbergen B. The relationship between stress shielding and bone resorption around total hip stems and the effects of flexible materials. Clinical Orthopaedics and Related Research. 1992; 27(274):124-134. PMid:1728998.

46. Sumner DR and Galante JO. Determinants of stress shielding: design versus materials versus interface. Clinical Orthopaedics and Related Research. 1992;274(274):202-212. PMid:1729005.

47. Rho JY, Kuhn-Spearing L and Zioupos P. Mechanical properties and the hierarchical structure of bone. Medical Engineering \& Physics. 1998; 20(2):92-102. http://dx.doi.org/10.1016/S13504533(98)00007-1. PMid:9679227.

48. Weiner S and Wagner HD. The material bone: structuremechanical function relations. Annual Review of Materials Science. 1998; 28(1):271-298. http://dx.doi.org/10.1146/annurev. matsci.28.1.271.

49. Mish CE. Contemporary implant dentistry. Canada: Elsevier; 2008. p. 645-667.

50. International Organization for Standardization - ISO. ISO/ DIS 14801:2014: dentistry, implants: dynamic fatigue test for endosseous dental implants. Geneva.

51. Sabirov I, Perez-Prado MT, Molina-Aldareguia JM, Semenova IP, Salimgareeva GK and Valiev RZ. Anisotropy of mechanical properties in high-strength ultra-fine-grained pure Ti processed via a complex severe plastic deformation route. Scripta Materialia. 2011; 64(1):69-72. http://dx.doi.org/10.1016/j. scriptamat.2010.09.006.

52. Zheng C, Nie F, Zheng Y, Cheng Y, Wei S and Valiev RZ. Enhanced in vitro biocompatibility of ultrafine-grained titanium with hierarchical porous surface. Applied Surface Science. 2011; 257(13):5634-5640. http://dx.doi.org/10.1016/j. apsusc.2011.01.062.

53. Kim HS, Yoo SJ, Ahn JW, Kim DH and Kim WJ. Ultrafine grained titanium sheets with high strength and high corrosion resistance. Materials Science and Engineering A. 2011; 528(2930):8479-8485. http://dx.doi.org/10.1016/j.msea.2011.07.074.

54. Symonova AA, Verezub ON, Sycheva AA, Verezub NV, Havin VL and Kaptay G. Surface grain coarsening and surface softening during machining of ultra-fine grained titanium. Journal of Mining and Metallurgy B: Metallurgy. 2012; 48(3):449-459. http://dx.doi.org/10.2298/JMMB121109056S.

55. Kolobov YR, Lipnitskii AG, Ivanov MB, Nelasov IV and Manokhin SS. Investigations of the thermal stability of the microstructure of titanium produced by intense plastic deformation. Russian Physics Journal. 2012; 54(8):918-936. http://dx.doi.org/10.1007/s11182-011-9700-6.

56. Valiev RZ, Semenova IP, Latysh VV, Shcherbakov AV and Yakushina EB. Nanostructured titanium for biomedical applications: new developments and challenges for commercialization. Nanotechnologies in Russia. 2008; 3(9-10):593-601. http:// dx.doi.org/10.1134/S1995078008090097.

57. Semenova IP, Salimgareeva GK, Latysh VV, Kunavin SA and Valiev RZ. Fatigue resistance of titanium with ultrafine-grained structure. Metal Science and Heat Treatment. 2009; 51(1-2):8791. http://dx.doi.org/10.1007/s11041-009-9123-y.

58. Sergueeva AV, Stolyarov VV, Valiev RZ and Mukherjee AK. Advanced mechanical properties of pure titanium with ultrafine 
grained structure. Scripta Materialia. 2001; 45(7):747-752. http://dx.doi.org/10.1016/S1359-6462(01)01089-2.

59. Ko YG, Shin DH, Park KT and Lee CS. An analysis of the strain hardening behavior of ultra-fine grain pure titanium. Scripta Materialia. 2006; 54(10):1785-1789. http://dx.doi. org/10.1016/j.scriptamat.2006.01.034.

60. Sauvage X, Wilde G, Divinski SV, Horita Z and Valiev RZ. Grain boundaries in ultrafine grained materials processed by severe plastic deformation and related phenomena. Materials Science and Engineering A. 2012; 540:1-12. http://dx.doi. org/10.1016/j.msea.2012.01.080.

61. Pachla W, Kulczyk M, Sus-Ryszkowska M, Mazur A and Kurzydlowski KJ. Nanocrystalline titanium produced by hydrostatic extrusion. Journal of Materials Processing Technology. 2008; 205(1-3):173-182. http://dx.doi.org/10.1016/j. jmatprotec.2007.11.103.

62. Raab GI, Valiev RZ, Gunderov DV, Lowe TC, Misra A and Zhu YT. Long-length ultrafine-grained titanium rods produced by ECAP-conform. Materials Science Forum. 2008; 584:80-85. http://dx.doi.org/10.4028/www.scientific.net/MSF.584-586.80.

63. Raab GJ, Valiev RZ, Lowe TZ and Zhu YT. Continuous processing of ultrafine grained Al by ECAP-conform. Materials Science and Engineering A. 2004; 382(1-2):30-34. http://dx.doi. org/10.1016/j.msea.2004.04.021.

64. Valiev RZ and Langdon TG. Principles of equal-channel angular pressing as a processing tool for grain refinement. Progress in Materials Science. 2006; 51(7):881-981. http:// dx.doi.org/10.1016/j.pmatsci.2006.02.003.

65. Valiev RZ, Sabirov I, Zhilyaev AP and Langdon TG. Bulk nanostructured metals for innovative applications. JOM. 2012; 64(10):1134-1142. http://dx.doi.org/10.1007/s11837-012-0427-9.

66. Jia D, Wang YM, Ramesh KT, Ma E, Zhu YT and Valiev RZ. Deformation behavior and plastic instabilities of ultrafine-grained titanium. Applied Physics Letters. 2001; 79(5):611-613. http:// dx.doi.org/10.1063/1.1384000.
67. Popov AA, Pyshmintsev IY, Demakov SL, Illarionov AG, Lowe TC, Sergeyeva AV, et al. Structural and mechanical, properties of nanocrystalline titanium processed by severe plastic deformation. Scripta Materialia. 1997; 37(7):1089-1094. http://dx.doi.org/10.1016/S1359-6462(97)00210-8.

68. Stolyarov VV, Zhu YT, Lowe TC, Islamgaliev RK and Valiev RZ. A two step SPD processing of ultrafine-grained titanium. Nanostructured Materials. 1999; 11(7):947-954. http://dx.doi. org/10.1016/S0965-9773(99)00384-0.

69. Valiev RZ, Sergueeva AV and Mukheijee AK. The effect of annealing on tensile deformation behavior of nanostructured SPD titanium. Scripta Materialia. 2003; 49(7):669-674. http:// dx.doi.org/10.1016/S1359-6462(03)00395-6.

70. Semenova IP, Valiev RZ, Yakushina EB, Salimgareeva GH and Lowe TC. Strength and fatigue properties enhancement in ultrafine-grained Ti produced by severe plastic deformation. Journal of Materials Science. 2008; 43(23-24):7354-7359. http://dx.doi.org/10.1007/s10853-008-2984-4.

71. Mendes AA Fo, Rovere CA, Kuri SE, Sordi VL and Ferrante M. A general study of commercially pure Ti subjected to severe plastic deformation: microstructure, strength and corrosion resistance. Materia. 2010; 15:286-292.

72. Mendes AA Fo, Sordi VL and Ferrante M. The effects of severe deformation on some properties relevant to Ti implant. Materials Research. 2012; 15(1):27-31. http://dx.doi.org/10.1590/S151614392011005000102.

73. Yerramshetty JS and Akkus O. The associations between mineral crystallinity and the mechanical properties of human cortical bone. Bone. 2008; 42(3):476-482. http://dx.doi.org/10.1016/j. bone.2007.12.001. PMid:18187375.

74. Kloss FR, Steinmüller-Nethl D, Stigler RG, Ennemoser T, Rasse $\mathrm{M}$ and Hächl $\mathrm{O}$. In vivo investigation on connective tissue healing to polished surfaces with different surface wettability. Clinical Oral Implants Research. 2011; 22(7):699-705. http:// dx.doi.org/10.1111/j.1600-0501.2010.02038.x. PMid:21087321. 